\title{
ANALISIS FAKTOR-FAKTOR YANG MEMPENGARUHI PENYERAPAN TENAGA KERJA SEKTOR INDUSTRI DI SUMATERA UTARA
}

\author{
Dian Novianti Sitompul \\ Program Pascasarjana Ilmu Ekonomi Universitas Negeri Medan \\ Sumatera Utara, Indonesia \\ Telp: +62813 6161 7905E-mail: sitompulpangeran@yahoo.co.id
}

\begin{abstract}
Abstrack
North Sumatra is a province that has a fundamental problem of high unemployment. Judging from the years 1994-2010, overall pengengguran is the biggest challenge still facing the North Sumatra due to termination of employment due to the economic crisis, rising raw material prices significantly from the various sub-industries are incorporated in the manufacturing category. On the other hand the costs for labor and increase the added value of the resulting output is a condition that must be considered. This research aims to analyze the influence of GDP, the number of industries, inflation and the minimum wage on employment in the industrial sector of North Sumatra simultaneously and partially. The data used are secondary data sourced from North Sumatra Province namely BPS GDP variable, the number of industries, inflation, wages and employment industries in the province of North Sumatra as time series from 1994 till ,2010. The results of this research can be concluded that simultaneous simultaneously change the variable GDP, inflation, industrial, and UMR significantly affect the demand for industrial labor in the province of North Sumatra. Furthermore, partially concluded that GDP variable, and the number of positive effect on demand for industrial labor industry, while inflation and minimum wage variables negatively affect the demand for industrial labor in the province of North Sumatra.The results also showed that the most dominant variable effect on the demand for labor in the industrial sector of the province of North Sumatra is the number of industries.
\end{abstract}

Key words:Industry Sector Employment, GDP, inflation, industrial, and UMR

QE Journal | Vol.03 - No.01 - 28 


\section{PENDAHULUAN}

Dersoalan pokok yang dihadapi Indonesia umumnya dan Sumatera Utara khususnya dalam bidang ketenagakerjaan adalah kelebihan tenaga kerja serta kecilnya kesempatan kerja yang tercipta pada setiap sektor sehingga terjadi pengangguran. Selain terjadi ketidakseimbangan antara percepatan pertambahan jumlah angkatan kerja dengan pergerakan kesempatan kerja, ternyata karena perkembangan tekhnologi prasyarat yang dibutuhkan kesempatan lapangan kerja baru tidak dipenuhi pencari kerja. Artinya, kualitas pengangguran tidak dapat memenuhi prasyarat lowongan yang ada.

Berikut ini grafik perkembangan jumlah tenaga kerja industri besar sedang (dalam jiwa), inflasi (dalam persen), PDRB dan UMR (dalam rupiah) tahun amatan 1994-2010 adalah sebagai berikut:

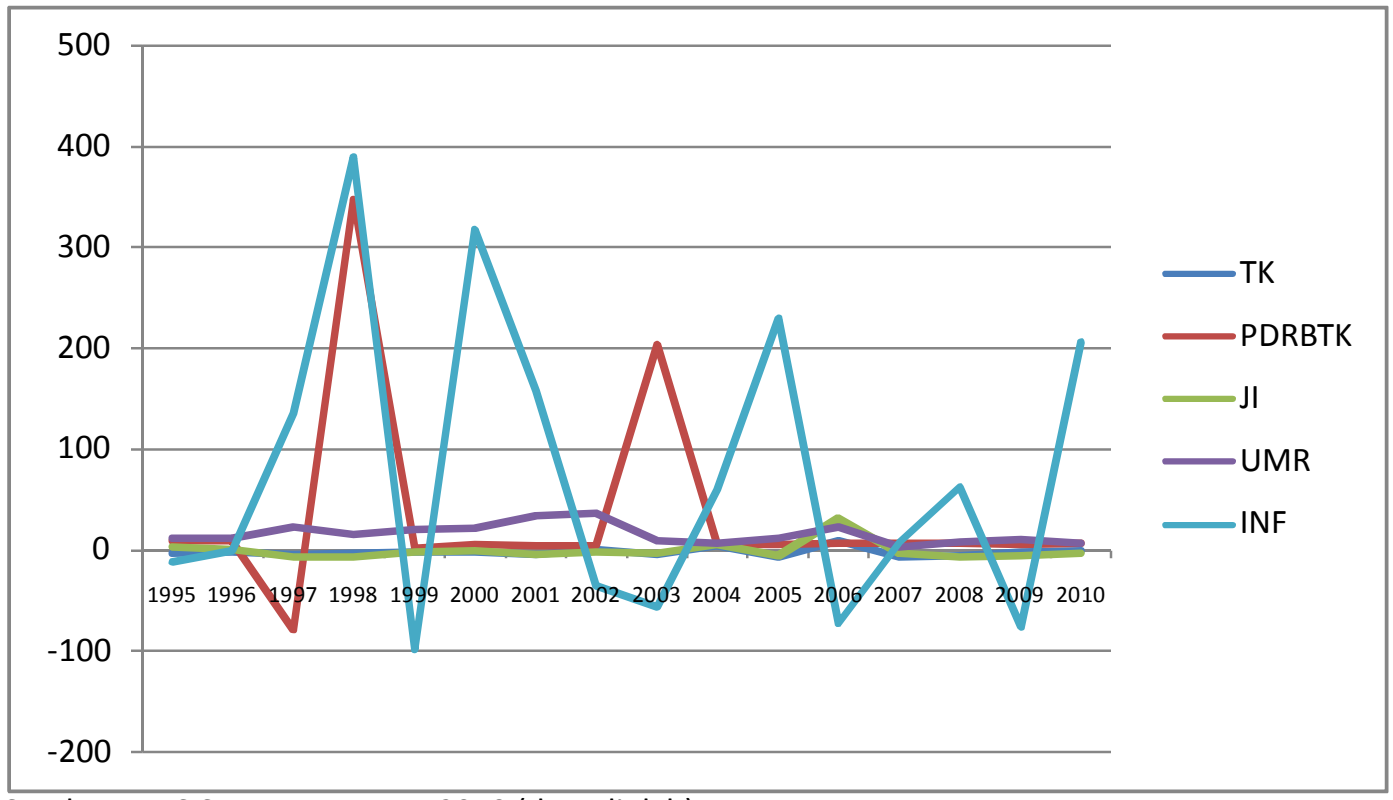

Sumber : BPS Sumatera Utara, 2010 (data diolah)

Gambar 1. Perkembangan Jumlah Tenaga Kerja IBS (TK), Inflasi (INF), PDRB Konstan, Jumlah IBS (JI) dan UMR

Berdasarkan Gambar 1. diatas dapat dilihat masing-masing perkembangan variabel bahwa perkembangan jumlah penyerapan tenaga kerja sektor industri besar sedang telah terjadi secara berfluktuasi dan cenderung 
menurun. Penurunan jumlah penyerapan tenaga kerja justru terjadi bukan pada masa awal krisis moneter tahun 1997 yang mencapai 4,73 persen melainkan pada tahun 2005 sebesar 6,69 persen dari 158,877 jiwa pada tahun 2004 menjadi 148,249 jiwa. Sedangkan peningkatan jumlah penyerapan tenaga kerja tertinggi terjadi pada tahun 2006 yang mencapai 9,67 persen dari 148,249 jiwa pada tahun 2005 menjadi 162,591 jiwa.

Bila jumlah penyerapan tenaga kerja dikaitkan dengan PDRB konstan di Sumatera Utara, dapat di lihat bahwa ada hubungan positif peningkatan besaran PDRB dengan penurunan jumlah penyerapan tenaga kerja sektor industri.Perkembangan PDRB mengindikasikan daerah tersebut sedang berkembang, dan sedang menggeliat sektor perekonomiannya khususnya industri.Turunnya PDRB sebesar 78,96 persen pada tahun 1998 menjadi 4.989,74 milyar dari tahun 1997 sebesar 23.714,74, milyar membuat terjadinya penurunan penyerapan tenaga kerja industri besar sedang sebesar 4,73 persen. Ternyata tidak semua naik turunnya PDRB diikuti dengan turun naiknya penyerapan tenaga kerja. Hal ini bisa dilihat pada tahun 2003, naiknya PDRB pada tahun tersebut sebesar 203,97 persen justru diikuti dengan turunnya jumlah penyerapan tenaga kerja sebesar 3,91 persen. Hal ini menunjukkan adanya ketidakkonsistenan peningkatan besaran PDRB dengan kenyataan penyerapan tenaga kerja dilapangan.

Apabila jumlah penyerapan tenaga kerja dikaitkan dengan tingkat inflasi yang terjadi di Sumatera Utara, dapat dilihat ada hubungan negatif antara peningkatan inflasi terhadap penurunan jumlah tenaga kerja sektor industri. Naiknya inflasi menyebabkan seluruh biaya produksi industri akan semakin mahal, sementara kemampuan daya beli masyarakat semakin berkurang. Tentunya ini akan menyulitkan industri untuk berkembang, bahkan untuk mengatasi permasalahan tersebut tidak jarang ditempuh dengan PHK demi mengefisiensikan segala pengeluaran. Hal ini terjadi misalnya pada tahun 1998 dimana pada tahun tersebut terjadi krisis moneter di seluruh Indonesia khususnya di Sumatera Utara. Naiknya inflasi sebesar 390,09 persen pada tahun 1998 menjadi 83,56 persen dari tahun 1997 sebesar 17,05 persen, membuat terjadi penurunan penyerapan tenaga kerja industri besar sedang sebesar 2,48 persen. Namun ternyata tidak semua naik turunnya inflasi diikuti dengan turun naiknya penyerapan tenaga kerja. Hal ini bisa diamati misalnya pada tahun 2003, turunnya inflasi pada tahun tersebur sebesar 55,89 persen justru diikuti

QE Journal | Vol.03 - No.01 - 30 
dengan turunnya jumlah penyerapan tenaga kerja sebesar 3,91 persen. Hal ini menunjukkan adanya ketidakkonsistenan teori tentang inflasi dengan kenyataan.

Jika penyerapan tenaga kerja ini dikaitkan dengan jumlah industri besar sedang, maka dapat diketahui semakin banyak jumlah industri, maka penyerapan tenaga kerja akan semakin besar. Banyaknya investasi sektor industri memungkin jumlah industri akan semakin besar. Secara umum, naik turunnya jumlah industri besar sedang di Sumatera Utara sejalan dengan naik turunnya jumlah tenaga kerja. Hal ini terjadi misalnya pada tahun 1998, turunnya jumlah industri sebesar 6,53 persen dari 1.088 pada tahun 1997 menjadi 1.017. Namun ternyata tidak semua naik turunnya jumlah industri diikuti dengan naik turunnya jumlah penyerapan tenaga kerja. Hal ini khususnya bisa diamati misalnya pada tahun 1995, naiknya jumlah industri besar sedang pada tahun tersebut sebesar 3,52 persen justru diikuti dengan turunnya jumlah penyerapan tenaga kerja sebesar 2,38 persen. Hal ini menunjukkan adanya ketidakkonsistenan bahwa naiknya jumlah industri dengan kenyataan jumlah penyerapan tenaga kerja.

Kemudian jika penyerapan tenaga kerja ini dikaitkan dengan tingkat upah, maka dapat diketahui bahwa ada kecenderungan hubungan negatif upah dengan penyerapan tenaga kerja di Sumatera Utara. Meningkatnya jumlah upah akan menyebabkan pembengkakkan pengeluaran industri yang akan menurunkan besaran laba optimum industri tersebut. Untuk mengatasi permasalahan tersebut tidak jarang suatu industri harus menempuh dengan cara pengurangan penyerapan tenaga. Hal ini dilakukan sematamata untuk menghemat pengeluaran dan demi tercapainya laba optimum sektor industri tersebut. Secara umum kenyataannya naiknya tingkat upah cenderung diikuti dengan turunnya jumlah tenaga kerja sektor industri besar sedang. Hal ini terjadi misalnya pada tahun 2001 dimana pada tahun tersebut tingkat upah meningkat sebesar 34,05 persen dari 271.800 rupiah pada tahun 2000 menjadi 364.335 rupiah. Namun ternyata tidak semua naiknya tingkat upah diikuti dengan turun naiknya penyerapan tenaga kerja. Hal ini bisa diamati misalnya pada tahun 2004, naiknya tingkat upah pada tahun tersebut sebesar 22,14 persen justru diikuti dengan naiknya jumlah penyerapan tenaga kerja sebesar 4,26 persen. Hal ini menunjukkan 
adanya ketidakkonsistenan meningkatnya upah dengan kenyataan jumlah penyerapan tenaga kerja dilapangan.

\section{METODE PENELITIAN}

Data yang digunakan adalah data sekunder dengan jenis data timeseries selama kurun waktu 1994 - 2010. Model analisis yang digunakan adalah model analisis dengan menggunakan metode Ordinary Least Square (OLS). Dalam penelitian ini, faktor-faktor yang mempengaruhi penyerapan tenaga kerja sektor industri di Sumatera Utara akan dianalisis dengan fungsi matematis sebagai berikut :

$$
\mathrm{TK}=\mathrm{f}(\mathrm{PDRBTK}, \mathrm{JI}, \mathrm{INF}, \mathrm{UP})
$$

Dari persamaan 1, kemudian ditransformasikan model tersebut kedalam bentuk logaritma dengan hasil sebagai berikut:

$$
\log (\mathrm{TKI})=\beta \mathrm{o}+\beta 1 \log (\mathrm{PDRBTK})+\beta 2 \log (\mathrm{JI})+\beta 3 \log (\mathrm{INF})+
$$
$\beta 4 \log (\mathrm{UP})+\mathrm{e}(2)$

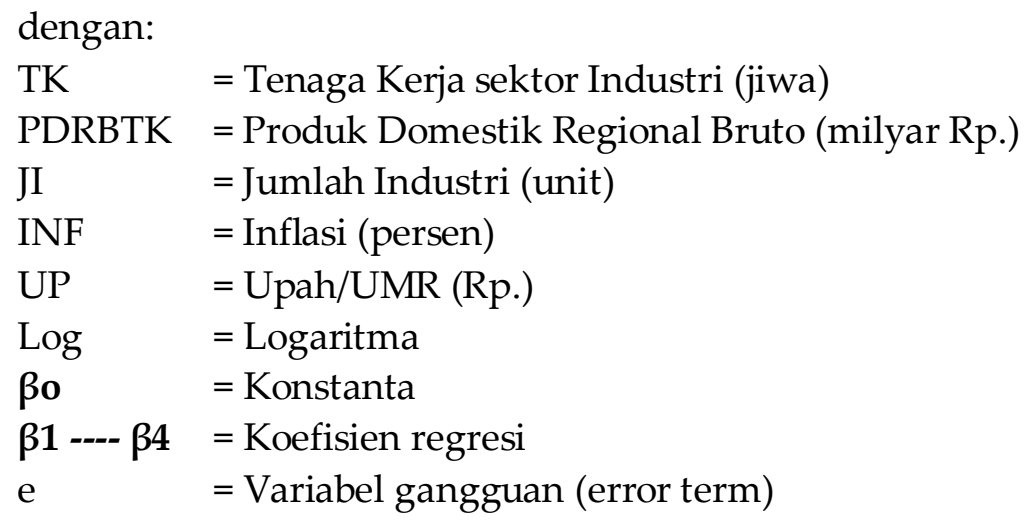

Pengujian terhadap asumsi klasik bertujuan untuk mengetahui apakah model regresi tersebut baik atau tidak jika digunakan untuk melakukan penaksiran. Untuk mendapatkan hasil memenuhi sifat tersebut perlu dilakukan pengujian asumsi klasik yang meliputi: uji multikolinearitas, uji autokolerasi, dan uji normalitas.

Uji Multikolinieritas bertujuan untuk menguji apakah model regresi ditemukan adanya korelasi antar variabel bebas atau independen. Apabila nilai $\mathrm{R}^{2}$ yang dihasilkan dalam suatu estimasi model regresi empiris sangat tinggi, tetapi secara individual variabel-variabel independen banyak yang

QE Journal | Vol.03 - No.01 - 32 
tidak signifikan mempengaruhi variabel dependen, hal ini merupakan salah satu indikasi terjadinya multikolinearitas (Gujarati, 2006:85).

Asumsi model regresi linear adalah bahwa faktor pengganggu atau residual mempunyai nilai rata-rata yang sama dengan nol, tidak berkorelasi dan mempunyai varian yang konstan. Untuk mengetahui normal atau tidaknya faktor pengganggu dilakukan dengan J-B test (jarquebera test).

Uji ini menggunakan hasil estimasi residual dan chi square probability distribution yaitu dengan membandingkan JB hitung $=\chi^{2}$ hitung dengan nilai $\chi^{2}$ tabel dengan kriteria :

a. Bila JB hitung $>$ nilai $\chi^{2}$ tabel, maka hipotesis yang menyatakan bahwa residual berdistribusi normal akan ditolak.

b. Bila JB hitung $<$ nilai $\chi^{2}$ tabel maka hipotesis yang menyatakan bahwa residual berdistribusi normal akan diterima.

Selain itu cara untuk mengetahui hasil estimasi residual dan chi square probability distribution yaitu dengan membandingkan Prob. JB hitung pada taraf alpha 5 persen dengan kriteria :

c. Bila Prob. JB hitung $>0,05$, maka hipotesis yang menyatakan bahwa residual berdistribusi normal akan diterima.

d. Bila Prob. JB hitung 0,05, maka hipotesis yang menyatakan bahwa residual berdistribusi normal akan ditolak.

Ketepatan fungsi regresi sampel dalam menaksir nilai aktual dapat diukur dari goodness of fit nya. Secara statistik, setidaknya ini dapat diukur dari, nilai statistik $F$, nilai statistik $t$, dan nilai koefisien determinansi $\left(R^{2}\right)$. Perhitungan statistik disebut signifikan secara statistik, apabila uji nilai statistiknya berada dalam daerah kritis (daerah dimana Ho ditolak). Sebaliknya, disebut tidak signifikan bila uji nilai statistiknya berada dalam daerah dimana Ho diterima.

Uji F digunakan untuk menguji apakah semua variabel independen atau bebas yang dimasukkan dalam model mempunyai pengaruh secara bersama-sama terhadap variabel dependen atau terikat. Tingkat signifikan dalam penelitian ini adalah 5\%, artinya risiko kesalahan mengambil keputusan adalah 5\% (Ghozali, 2006:78) 
Uji $\mathrm{t}$ menunjukkan seberapa jauh pengaruh satu variabel independen secara individual dalam menerangkan variasi variabel dependen. Tingkat signifikan dalam penelitian ini adalah 5\%, artinya risiko kesalahan mengambil keputusan adalah $5 \%$.

Uji koefisien determinasi digunakan untuk mengetahui tingkat ketepatan yang paling baik dalam analisis regresi, hal ini ditunjukkan oleh besarnya koefisien determinasi $\left(R^{2}\right)$. Nilai koefisien determinasi adalah 0 sampai 1 . Semakin $\mathrm{R}^{2}$ mendekati 0 maka semakin kecil kemampuan semua variabel independen dalam menjelaskan perubahan nilai variabel dependen. Semakin $\mathrm{R}^{2}$ mendekati 1 maka semakin besar pengaruh semua variabel independen terhadap variabel dependen (Ghozali, 2006:88).

Koefisien determinasi dapat dicari dengan rumus (Gujarati,1995:122) :

$$
\mathrm{R}^{2}=\frac{E S S}{T S S}=1-\frac{\sum e i^{2}}{\sum Y i^{2}}
$$

Uji koefisien determinasi digunakan untuk mengetahui tingkat ketepatan yang paling baik dalam analisis regresi, hal ini ditunjukkan oleh besarnya koefisien determinasi $\left(R^{2}\right)$. Nilai koefisien determinasi adalah 0 sampai 1 . Semakin $\mathrm{R}^{2}$ mendekati 0 maka semakin kecil kemampuan semua variabel independen dalam menjelaskan perubahan nilai variabel dependen. Semakin $\mathrm{R}^{2}$ mendekati 1 maka semakin besar pengaruh semua variabel independen terhadap variabel dependen. Secara umum koefisien determinasi untuk data crossection relatif rendah karena adanya variasi yang besar antara masing-masing pengamatan, sedangkan data time series biasanya mempunyai koefisien determinasi yang tinggi (Ghozali, 2006:88).

Koefisien determinasi dapat dicari dengan rumus (Gujarati,1995:122) :

$$
\mathrm{R}^{2}=\frac{E S S}{T S S}=1-\frac{\sum e i^{2}}{\sum Y i^{2}}
$$

\section{HASIL DAN PEMBAHASAN}

Pengujian regresi yang digunakan dalam penelitian ini menggunakan regresi data time series dengan pendekatan model OLS (ordinary least square). Penelitian ini dicerminkan melalui model estimasi regresi linear berganda yang didasarkan atas hasil pengolahan data dengan 
menggunakan program Eviews 5.1. yang ditunjukkan pada persamaan sebagai berikut:

$$
\begin{gathered}
\log (\text { TKI })=12.05094+0.007880 \log (\text { PDRBTK })+0.193422 \log (\mathrm{JI})-0.003084 \\
\log (\text { INF })-0.116016 \log (\text { UP })
\end{gathered}
$$

Berdasarkan model tersebut diketahui bahwa variabel PDRB, inflasi, jumlah industri, dan UMR berpengaruh terhadap penyerapan tenaga kerja sektor industri di Sumatera Utara.

Nilai koefisien mampu menunjukkan besarnya proporsi perubahan besaran penyerapan tenaga kerja sektor industridalam satuan variabel. Adapun koefisien variabel berdasarkan hasil penelitian dapat dilihat pada mosel berikut :

$$
\begin{gathered}
\log (\text { TKI })=12.05094+0.007880 \log (\text { PDRBTK })+0.193422 \log (\text { JI })-0.003084 \\
\log (\text { INF })-0.116016 \log (\text { UP })
\end{gathered}
$$

\section{Variabel PDRB Terhadap Penyerapan Tenaga Kerja Sektor Industri di Sumatera Utara}

VariabelPDRB ternyata tidak memiliki hubungan terhadap penyerapan tenaga kerja sektor industri di Sumatera Utara. Artinya, naik turunnya PDRB tidak berdampak kepada naik turunnya Peningkatan penyerapan tenaga kerja sektor industri di Sumatera Utara Hasil penelitian ini mengungkapkan bahwa. PDRB tidak berpengaruh signifikan terhadap penyerapan tenaga kerja sektor industri di Sumatera Utara. Hal ini dikarenakan perkembangan PDRB yang terjadi ternyata tidak berdampak terhadap perkembangan penyerapan tenaga kerja.

\section{Variabel Jumlah Industri Terhadap Penyerapan Tenaga Kerja Sektor Industri di Sumatera Utara}

Variabeljumlah industri ternyata memiliki hubungan positif dan signifikan terhadap penyerapan tenaga kerja sektor industri di Sumatera Utara. Peningkatan penyerapan tenaga kerja sektor industri di Sumatera Utara terjadi karena perubahan peningkatan jumlah industri. Hasil penelitian ini mengungkapkan bahwa setiap kenaikan jumlah industri sebesar 1 persen, maka akan meningkatkan besaran penyerapan tenaga kerja sektor industri di Sumatera Utara sebesar 0.193422 persen.

QE Journal | Vol.03 - No.01 - 35 
Hal ini menunjukkan bahwa perkembangan jumlah industri setiap tahunnya sejalan dengan penyerapan tenaga kerja sektor industri secara nyata pada setiap tahunnya di Sumatera Utara. Ini bisa dipahami, meningkatnya jumlah investasi, jumlah deposito khususnya untuk sektor industri, maka akan menggiatkan para pelaku usaha untuk mengembangkan usaha atau industrinya. Upaya ini bisa dilakukan melalui ekspansi wilayah industri dan akan membangun industri yang baru. Naiknya jumlah industri terus menerus tentunya akan meningkatkan penyerapan tenaga kerja. Ini merupakan hal yang sangat baik sebagai upaya pemerataan dan penyerapan tenaga kerja sehingga jumlah pengangguran dapat dikurangi yang sejalan dengan penurunan tingkat kemiskinan. Oleh sebab itu, hasil penelitian ini menunjukkan bahwa semakin jumlah industri suatu daerah, maka akan meningkatkan penyerapan tenaga kerja sektor industri khususnya di Sumatera Utara.

\section{Variabel Inflasi Terhadap Penyerapan Tenaga Kerja Sektor Industri di Sumatera Utara}

Variabelinflasi ternyata tidak berhubungan terhadap penyerapan tenaga kerja sektor industri di Sumatera Utara. Penurunan penyerapan tenaga kerja sektor industri di Sumatera Utara terjadi bukan karena perubahan peningkatan inflasi. Hasil penelitian ini mengungkapkan bahwa. inflasi tidak berpengaruh signifikan terhadap penyerapan tenaga kerja sektor industri di Sumatera Utara. Hal ini dikarenakan perkembangan inflasi yang terjadi ternyata tidak berdampak terhadap perkembangan penyerapan tenaga kerja sektor industri di Suamatera Utara.

Perkembangan inflasi setiap tahunnya berbanding terbalik dengan penyerapan tenaga kerja pada setiap tahunnya. Hal ini bisa dipahami, naiknya harga terus menerus akan meningkatkan biaya produksi perusahaan, yang selanjutnya akan meningkatkan harga per unit barang yang diproduksi

\section{Variabel UMR Terhadap Penyerapan Tenaga Kerja Sektor Industri di Sumatera Utara}

VariabelUMR ternyata memiliki hubungan positif dan signifikan terhadap penyerapan tenaga kerja sektor industri di Sumatera Utara.

Penurunan penyerapan tenaga kerja sektor industri di Sumatera Utara terjadi karena perubahan peningkatan UMR. Hasil penelitian ini

QE Journal | Vol.03 - No.01 - 36 
mengungkapkan bahwa setiap kenaikan UMR sebesar 1 persen, maka akan menurunkan besaran penyerapan tenaga kerja sektor industri di Sumatera Utara sebesar 0.116016 persen.

Hasil penelitian ini menegaskan bahwa upah berpengaruh negatif dan signifikan terhadap penyerapan tenaga kerja industri di Sumatera Utara. Kenaikan upah setiap tahunnya berbanding terbalik dengan penyerapan tenaga kerja secara nyata pada setiap tahunnya

\section{SIMPULAN DAN SARAN}

\section{SIMPULAN}

1. Secara simultan keempat variabel tersebut menunjukkan nilai F-Stat yang cukup tinggi yaitu 37.46127 dengan prob. sebesar $0.000001<0.05$, sehingga Ho ditolak yang berarti bahwa secara bersama-sama perubahan variabel PDRB, inflasi, jumlah industri, dan UMR berpengaruh terhadap penyerapan tenaga kerja sektor industri di Sumatera Utara

2. Secara parsial disimpulkan bahwa variabel PDRB, dan inflasi tidak berpengaruh signifikan terhadap penyerapan tenaga kerja sektor industri, sedangkan variabel jumlah dan UMR berpengaruh signifikan terhadap penyerapan tenaga kerja sektor industri di Sumatera Utara.

3. Variabel PDRB, inflasi, jumlah industri, dan UMR berpengaruh terhadap penyerapan tenaga kerja sektor industri di Sumatera Utara sebesar 92,58 persen. Serta sisanya 7,42 persen dipengaruhi variabel lain.

4. Hasil penelitian ini menunjukkan bahwa variabel yang paling dominan berpengaruh dominan terhadap penyerapan tenaga kerja sektor industri di Sumatera Utara adalah jumlah industri.

\section{SARAN}

1. Pemerintah selayaknya mengendalikan angka pengangguran, salah satu cara agar dapat menekan angka pengangguran yakni dapat dilakukan misalnya dengan menciptakan lapangan kerja yang banyak bagi masyarakat. Selain itu, pemerintah perlu meningkatkan iklim investasi demi meningkatkan jumlah industri yang lebih banyak lagi.

QE Journal | Vol.03 - No.01 - 37 
2. Pemerintah bekerjasama dengan Bank Indonesia perlu mengendalikan laju inflasi dengan cara memberi aturan baru terhadap import barang dari luar negeri sehingga barang Indonesia bisa dieksport dengan harga yang tinggi.

3. Pemerintah perlu menetapkan upah minimum yang relevan demi menyelamatkan industri dan tenaga kerja yang ada di Sumatera Utara.

4. Kepada peneliti selanjutnya, diharapkan mengidentifikasi variabelvariabel lainnya yang dapat mempengaruhi penyerapan tenaga kerja sektor industri.

\section{DAFTAR PUSTAKA}

Amelia,2005. Pengantar Ekonomi Sumber Daya Manusia. Tarsito, Bandung.

Badan Pusat Statistik. Sumatera Utara dalam Angka Tahun 2002. Sumatera Utara.

Sumatera Utara dalam Angka Tahun 2005. Sumatera Utara.

2001-2010. Pendapatan Nasional Indonesia. BPS. Sumatera Utara.

2010. Berita Statistik. Nomor Realese : No. 12/02/12/Th.XIII, 10 Februari2010; Nomor Realese : No. 07/02/12/Th.XIII, 01 Februari 2010; NomorRealese : No. 04/01/12/Th.XIII, 04 Januari 2010; Nomor Realese : No.01/01/12/Th.XIII, 4 Januari 2010. Medan.

Bellante, Don dan Jackson, Mark. 1990. Ekonomi Ketenagakerjaan. LP FE UI, Jakarta.

Boediono, 1982 Ekonomi Mikro, BPFE, Yogyakarta.

Departemen Tenaga Kerja dan Transmigrasi. 2008. Data Upah Minimum Tahun 2001-2010. Sumatera Utara: DEPNAKERTRANS.

2007. Profil Sumberdaya Manusia Indonesia. DEPNAKERTRANS, Jakarta.

2004. Rencana Tenaga Kerja Nasional 2004-2009.http: //www.Nakertrans.go.id.

Dumairy. 1996. Perekonomian Indonesia. Erlangga, Jakarta

Gujarati, Damodar. 2006. Ekonometrika Dasar. Trans. Sumarno Zain. Jakarta.Erlangga. 
Luthfi, Muhammad Idris. 2011. Analisis Determinan Kesempatan Kerja Sektor Industri Di Sumatera Utara. Tesis. Medan : Program Pascasarjana Universitas Sumatera Utara.

Lubis, Mitra Musika. 2010. Analisis Faktor-Faktor Yang Mempengaruhi Penyerapan Tenaga Kerja Sektor Pertanian Di Sumatera Utara. Tesis. Medan : Program Pascasarjana Universitas Sumatera Utara.

Mankiw, Gregory N.2003. Macroeconomics. Fifth Editions. New York. Worth Publishers. 41Madison Avenue.

Sholeh, Maimun. Permintaan dan Penawaran Tenaga Kerja Sektor Upah: Teori Serta Beberapa Potretnya di Indonesia. Universitas Negeri Yogyakarta.

Simanjuntak, Payaman.J 1998," Pengantar Ekonomi Sumber Daya Manusia". Jakarta: Lembaga Penerbit Fakultas Ekonomi Universitas Indonesia.

Sudarsono, dkk. 2007. Ekonomi Sumber Daya manusia. Karunia: Jakarta, Universitas Terbuka, Jakarta.

Sukirno, Sadono: Ekonomi Pembangunan, Medan: Borta Gorat, 1996.

Sukirno, Sadono. 2003. Pengantar Teori Makro Ekonomi Edisi Kedua. Jakarta.PT. Rajagrafindo Persada.

Todaro, Michael P. 1999. Pembangunan Ekonomi di Dunia Ketiga. Trans. HarisMunandar. Jakarta. Erlangga.

Winarno, Wing Wahyu. 2007. Analisis Ekonometrika dan Statistika dengan Eviews. Jogjakarta : UPP STIM YKPN.

Winardi, 1999. Pengantar Ilmu Ekonomi. Tarsito, Bandung

Dornbusch dan Fischer. 1995. Struktur Perekonomian dan Strategi Pembangunan Indonesia. Jakarta : UI-Press

Ehrenberg, Ronald G, 1998. Modern Labour Economic, Scoot and Foresman Company.

Nopirin (2000:47) Dasar-Dasar Manajemen Perekonomian Indonesia. Jakarta: PT. Rajagrafindo Persada. 
Prihartanti. 2007. Faktor- Faktor Yang Mempengaruhi Penyerapan Tenaga Kerja Sektor Industri di Kota Bogor. Tesis. Bogor : Institut Pertanian Bogor.

QE Journal | Vol.03 - No.01 - 40 